\title{
Validasi Pulse Oximeter dalam Penentuan Kadar Oksigen dalam Darah
}

\author{
Umi Salamah*, Asna Nur Izziyah dan Arifan Arif Raharjo \\ Program Studi Fisika, Universitas Ahmad Dahlan, Yogyakarta, Indonesia, 55166 Kode Pos \\ Email : *umi.salamah@fisika.uad.ac.id
}

Diterima (14 Juni 2020), Direvisi (14 Juli 2020)

\begin{abstract}
Level of oxygen saturation in blood is important to know the health condition of the body. If the human body lacks or excess oxygen, it will cause illness and other bodily system work disorders. One of the tools to detect oxygen saturation level is the Pulse oximeter. Previous research has successfully designed a Pulse oximeter based on Arduino. The pulse oximeter produces a photoplestymograph (PPG) signal that corresponds to the standard PPG signals in 20 test samples. PPG signals can be processed to provide information on oxygen saturation ( $\mathrm{SpO}$ ) levels in the blood. In this research, validation of the Pulse oximeter is compared with a commercial pulse oximeter, the digital oximeter JZK-301. The results obtained from this validation are the smallest deviation errors are $4.83 \%$ while the largest errata is $22.51 \%$. The greatest accuracy of $95.17 \%$, of respondents number 16 and the smallest accuracy are 77, 49\%, that is the number of respondents 12. The average deviation of 20 data is $12.82 \%$ with the resulting accuracy is $87,18 \%$. This indicates that the self-designed pulse oximeter has good efficiency and can be developed further.
\end{abstract}

Keywords: Validation Pulse oximeter, Photoplestymograph (PPG), SpO2.

\begin{abstract}
Abstrak. Kadar kejenuhan oksigen dalam darah merupakan hal yang penting untuk mengetahui kondisi kesehatan tubuh. Jika tubuh manusia kekurangan atau kelebihan oksigen maka akan menimbulkan penyakit dan gangguan sistem kerja tubuh yang lain. Salah satu alat yang digunakan untuk mendeteksi kadar kejenuhan oksigen dalam darah adalah pulse oximeter. Penelitian sebelumnya telah berhasil merancang bangun pulse oximeter berbasis Arduino. Pulse oximeter tersebut menghasilkan sinyal photoplestymograph (PPG) yang berkesesuaian dengan sinyal-sinyal standart PPG pada 20 sampel uji. Sinyal PPG tersebut dapat diolah untuk memberikan informasi kadar kejenuhan oksigen $\left(\mathrm{SpO}_{2}\right)$ dalam darah. Pada penelitian ini dilakukan validasi Pulse oximeter dengan membandingkan dengan pulse oximeter komersial yaitu oximeter digital JZK-301. Hasil yang diperoleh dari validasi ini adalah ralat simpangan terkecil adalah 4,83\% sedang ralat terbesar $22,51 \%$. Hal tersebut menghasilkan akurasi terbesar yaitu $95,17 \%$ yaitu pada nomor responden 16 dan akurasi terkecil adalah 77, $49 \%$ yaitu pada nomor responden 12. Rata-rata ralat simpangan dari 20 data adalah 12,82 $\%$ dengan akurasi yang dihasilkan adalah $87,18 \%$. Hal tersebut mengindikasikan pulse oximeter yang telah dirancang bangun sendiri tersebut mempunyai efisiensi yang yang cukup baik dan dapat dikembangkan lebih lanjut.
\end{abstract}

Kata kunci: Validasi Pulse oximeter, Photoplestymograph (PPG), SpO2.

\section{PENDAHULUAN}

Informasi kadar kejenuhan oksigen dalam darah merupakan hal yang sangat penting untuk mengetahui kondisi kesehatan tubuh manusia. Pada masa kritis, kadar oksigen dalam darah dipantau secara intensif sebagai salah satu parameter melakukan tindakan medis. Salah satu instrument yang digunakan untuk mengetahui kadar kejenuhan oksigen dalam darah adalah oximeter. Pada prinsipnya Pulse oximeter bekerja berdasarkan transport oksigen dalam 
darah. Transport oksigen dalam darah ada dua bentuk yaitu yang terlarut dalam plasma dan terikat dengan hemoglobin. Normalnya, sekitar $97 \%$ oksigen yang ditransport dari paru-paru ke jaringan terikat dengan hemoglobin dan sisanyanya $3 \%$ terlarut dalam plasma [1]. Oleh karena itu, maka akan terlihat perbedaan tertentu warna darah yang mengandung banyak oksigen dan mengandung sedikit oksigen. Jika kadar warna merah darah tersebut dapat diketahui maka dapat diketahui pula kadar oksigen darah. Dengan menggunakan sumber cahaya dapat menembus kulit manusia dan menggambarkan bagaimana spektrum warna darah dalam kulit tersebut, maka akan dapat diketahui kadar oksigen dalam darah orang tersebut.

Penelitian sebelumnya telah berhasil merancang bangun pulse oximeter menggunakan Arduino[2][4]. Dari penelitian tersebut diperoleh sinyal photoplestymograph (PPG) yang berkesesuaian dengan sinyal-sinyal PPG yang dihasilkan oleh penelitian-penelitian yang lainnya [5], [6]. Di samping itu telah diperoleh nilai $\mathrm{S}_{\mathrm{P}} \mathrm{O}_{2}$ dari 20 sampel uji yang mencerminkan kadar kejenuhan oksigen dalam darah. Namun demikian, dalam instrumentasi kesehatan akurasi dan kehandalan instrument medis menjadi hal sangat penting dan krusial untuk diperhatikan karena menyangkut informasi kesehatan manusia. Oleh sebab itu dalam pengembangan intrumentasi medis dilakukan berbagai tahapan pengujian. Pada penelitian ini dilakukan validasi pada pulse oximeter yang telah dirancang bangun tersebut dengan cara membandingkan dengan pulse oximeter komersial yang telah dikalibrasi sebelumnya.

\section{METODE PENELITIAN}

Validasi pulse oximeter dilakukan dengan dua langkah pengujian. Langkah pertama adalah dengan melakukan kalibrasi oximeter komersial. Langkah selanjutnya dengan membandingkan kejenuhan oksigen dalam darah hasil $\mathrm{S}_{\mathrm{P}} \mathrm{O}_{2}$ dari pulse oximeter yang telah dirancang bangun dengan pulse oximeter yang beredar komersial tersebut. Dari perbandingan tersebut akan diperoleh simpangan kedua pulse oximeter yang dapat digunakan untuk menghitung nilai ralatnya. Pulse oximeter diujikan pada 20 data sampel secara random.

Pulse oximeter yang dirancang menggunakan infamerah dan LED merah sebagai sumber cahaya serta fotodioda sebagai sensor cahaya sehingga menghasilkan sinyal PPG[7], [8]. Sedangkan nilai $\mathrm{SPO}_{2}$ dihitung berdasarkan persamaan empirik dengan metode pendekatan linear menggunakan grafik standart medis Pulse oximeter [9], [10]. Adapun persamaannya ditunjukan pada Persamaan 1 di bawah ini.

$$
S_{p} O_{2}=110-25 R_{0}
$$

dimana $\mathrm{S}_{p} \mathrm{O}_{2}$ kadar kejenuhan oksigen dalam darah dan $R_{0}$ perbandingan amplitudo pulsa sinyal PPG Infaremerah dengan LED merah [11].

Validasi dilakukan dengan menghitung $\mathrm{SpO} 2$ pulse oximeter hasil rancang bangun sendiri dan mencari ralat simpangan dengan oximeter acuannya. Dalam hal ini oximeter acuan digunakan oximeter komersial dengan tipe oximeter JZK-301. Adapun formulasi untuk menghitung ralat simpangan oximeter tersebut ditunjukan pada Persamaan 2 di bawah ini.

$$
S_{0}=\frac{X_{\text {acuan }}-X_{\text {hitung }}}{X_{\text {acuan }}} \times 100 \%
$$

Dimana $S_{0}$ simpangan, $X_{\text {acuan }}$ adalah nilai $\mathrm{SpO}_{2}$ oximeter komersial sedang $X_{\text {hitung }}$ adalah $\mathrm{SpO}_{2}$ oximeter yang dirancang bangun sendiri. Dari perhitungan simpangan di atas, maka akan diperoleh nilai validasi 
oximeter yang dirancang bangun sendiri dengan perumusan yang dituliskkan pada Persamaan 3.

$$
\text { Akurasi }=100 \%-S_{0}
$$

\section{HASIL DAN PEMBAHASAN}

Gambar 1 menunjukkan fotograf rangkaian elektronik rancang bangun pulsa oximeter. Sistem hardware tersebut terdiri atas arduino yang dirangkai dengan rangkaian probe yang terdiri atas sepasang LED sebagai sumber cahaya dan fotodioda sebagai sensor.

Sedangkan pada Gambar 2 ditunjukan sampel sinyal PPG dari dua responden yang diambil.

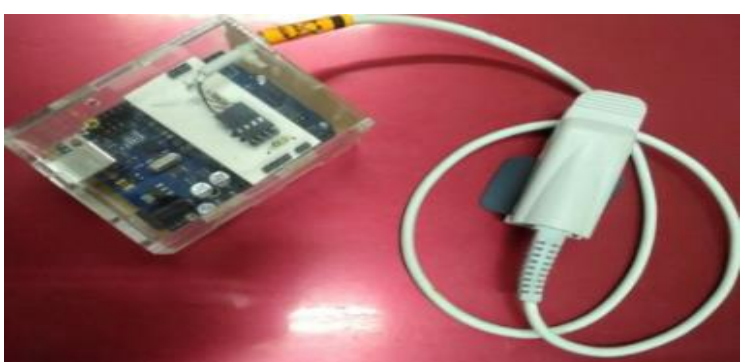

Gambar 1. Fotrograf modul mlektronik Pulse oximeter

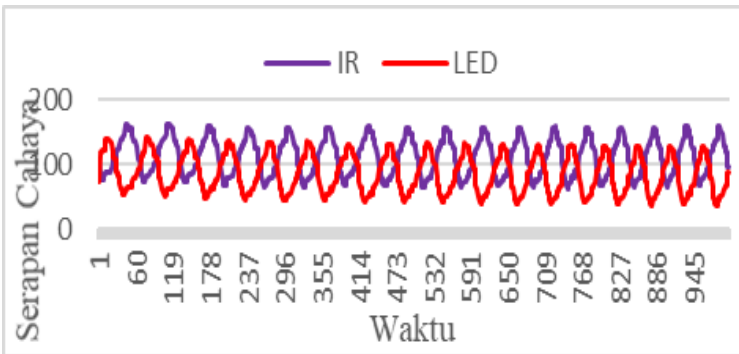

(a)



(b)

Gambar 2. Sampel sinyal PPG (a) laki-laki 21 tahun (b) perempuan 21 tahun
Tabel 1. Validasi Oximeter buatan sendiri dengan acuan oximeter komersial.

\begin{tabular}{|c|c|r|r|r|}
\hline No & $\begin{array}{c}\mathrm{SpO}_{2} \\
\text { yang } \\
\text { diuji }\end{array}$ & $\begin{array}{r}\mathrm{SpO}_{2} \\
\text { Oximeter } \\
\text { Komersial }\end{array}$ & $\begin{array}{c}\text { Simpangan } \\
(\%)\end{array}$ & $\begin{array}{c}\text { Akurasi } \\
(\%)\end{array}$ \\
\hline 1 & 82,12 & 94 & 12,64 & 87,36 \\
\hline 2 & 86,04 & 99 & 13,09 & 86,91 \\
\hline 3 & 86,56 & 99 & 12,57 & 87,43 \\
\hline 4 & 85,27 & 98 & 12,99 & 87,01 \\
\hline 5 & 86,43 & 95 & 9,02 & 90,98 \\
\hline 6 & 76,92 & 99 & 22,30 & 77,70 \\
\hline 7 & 85,73 & 99 & 13,40 & 86,60 \\
\hline 8 & 92,61 & 98 & 5,50 & 94,50 \\
\hline 9 & 86,40 & 98 & 11,84 & 88,16 \\
\hline 10 & 83,90 & 99 & 15,25 & 84,75 \\
\hline 11 & 86,13 & 99 & 13,00 & 87,00 \\
\hline 12 & 74,39 & 96 & 22,51 & 77,49 \\
\hline 13 & 88,17 & 98 & 10,03 & 89,97 \\
\hline 14 & 88,93 & 99 & 10,17 & 89,83 \\
\hline 15 & 81,24 & 98 & 17,10 & 82,90 \\
\hline 16 & 94,21 & 99 & 4,84 & 95,16 \\
\hline 17 & 87,72 & 98 & 10,48 & 89,51 \\
\hline 18 & 84,27 & 99 & 14,88 & 85,12 \\
\hline 19 & 88,49 & 99 & 10,62 & 89,38 \\
\hline 20 & 84,90 & 99 & 14,24 & 85,76 \\
\hline
\end{tabular}

Sinyal AC yang terdeteksi ini merupakan sebuah sebuah bentuk gelombang pulsatil dengan frekuensi yang terlihat, sedangkan sinyal DC merupakan sinyal frekuensi lemah yang melapisi sinyal AC. Sinyal AC ini menunjukkan tanda sinkronisasi antara perubahan volume darah, terutama pada arteri darah dengan setiap denyut nadi [13]-[15]. Kenaikan volume darah arteri menyebabkan penurunan jumlah cahaya yang menjangkau sensor fotodioda. Adapun data pengukuran nilai $\mathrm{S}_{\mathrm{P}} \mathrm{O}_{2}$ disajikan pada Tabel 1.

Dari Tabel 1 terlihat bahwa simpangan terkecil adalah 4,84\% pada responden 16 sedang simpangan terbesar $22,51 \%$ pada responden 12. Hal tersebut menghasilkan 
akurasi terbesar yaitu $95,17 \%$ yaitu pada nomor responden 16 dan akurasi terkecil adalah $77,49 \%$ yaitu pada nomor responden 12. Rata-rata ralat simpangan dari 20 data di atas $12,82 \%$ dengan akurasi yang dihasilkan adalah $87,18 \%$. Simpangan rata-rata yang dihasilkan dari pengujian tersebut masih cukup besar untuk sebuah instrumentasi medis. Namun demikian akurasi yang dihasilkan telah lebih dari $85 \%$ dan terdapat akurasi lebih dari $95 \%$ pada responden tertentu. Dari data tersebut, meskipun belum mendapat akurasi yang maksimal, oximeter yang telah dirancang bangun sendiri mempunyai akurasi yang cukup baik dan mempunyai potensi yang bagus untuk dikembangkan lebih lanjut.

\section{KESIMPULAN}

Penelitian ini telah memvalidasi oximeter hasil rancang bangun sendiri dengan nilai akurasi rata-rata $87,17 \%$ simpangan rata-rata $12,82 \%$. Hal tersebut mengindikasikan hasil yang cukup baik dan berpotensi untuk dikembangkan lebih lanjut.

\section{DAFTAR PUSTAKA}

[1] S. DeMeulenaere, "Pulse Oximetry: Uses and Limitations," J. Nurse Pract., 2007.

[2] U. Salamah, "Rancang Bangun Pulse Oximetry Menggunakan Arduino Sebagai Deteksi Kejenuhan Oksigen Dalam Darah," J. Penelit. Fis. dan Apl., 2016.

[3] U. Salamah and M. Sasono, "Effectivity comparison of red and infrared transmission spectrum for invivo oxygen detection in a homebuild oxymetry devices," in AIP Conference Proceedings, 2016.

[4] U. Salamah; M.Sasono, "Prosiding pertemuan dan presentasi ilmiah teknologi akselerator dan aplikasinya," vol. 17, no. November, pp. 33-37, 2015.
[5] J. Spigulis, "Optical noninvasive monitoring of skin blood pulsations," Appl. Opt., vol. 44, pp. 1851-1857, 2005.

[6] V. Gopikrishna, K. Tinagupta, and D. Kandaswamy, "Comparison of Electrical, Thermal, and Pulse Oximetry Methods for Assessing Pulp Vitality in Recently Traumatized Teeth," J. Endod., 2007.

[7] H. Njoum and P. A. Kyriacou, "Investigation of finger reflectance photoplethysmography in volunteers undergoing a local sympathetic stimulation," J. Phys. Conf. Ser., vol. 450, no. 1, 2013.

[8] J. E. Sinex, "Pulse oximetry: Principles and limitations," American Journal of Emergency Medicine. 1999.

[9] Smith Medical PM, "How can SpO 2 readings differ from manufacturer to manufacturer?," Man. Pulse Oximetry, pp. 2-5, 2007.

[10] G. Tusman et al., "Photoplethysmographic characterization of vascular tone mediated changes in arterial pressure : an observational study," $J$. Clin. Monit. Comput., vol. 0, no. 0, p. 0, 2018.

[11] S. Lopez, "Pulse oximeter Fundamentals and Design," AN4327, 2012 . 
[12] W. S. Johnston, "Development of a Signal Processing Library for Extraction of SpO2, HR , HRV , and RR from Photoplethysmographic Waveforms," 2006.

[13] C. D. Chua, I. M. Gonzales, E. Manzano, and M. C. Manzano, "Design and Fabrication of a NonInvasive Blood Glucometer Using Paired Photo-Emitter and Detector Near-Infrared LEDs," pp. 1-7, 2014.

[14] A. Liu, G. Li, W. Yan, and L. Lin, "Infrared Physics \& Technology Combined e ff ects of PPG preprocess and dynamic spectrum extraction on predictive performance of non-invasive detection of blood components based on dynamic spectrum," Infrared Phys. Technol., vol. 92, no. September 2017, pp. 436-442, 2018.

[15] R. Gonzalez, A. Manzo, J. Delgado, J. M. Padilla, U. P. De Valencia, and I. T. De Morelia, "A Computer Based Photoplethysmographic Vascular Analyzer through Derivatives," pp. 177-180, 2008. 
Umi Salamah, dkk: Validasi Pulse oximeter dalam Penentuan Kadar Oksigen dalam Darah 